\title{
Adenosine turnover in GtoPdb v.2021.3
}

\author{
Detlev Boison ${ }^{1}$
}

1. R. S. Dow Neurobiology Laboratories, USA

\begin{abstract}
A multifunctional, ubiquitous molecule, adenosine acts at cell-surface $\mathrm{G}$ protein-coupled receptors, as well as numerous enzymes, including protein kinases and adenylyl cyclase. Extracellular adenosine is thought to be produced either by export or by metabolism, predominantly through ecto-5'nucleotidase activity (also producing inorganic phosphate). It is inactivated either by extracellular metabolism via adenosine deaminase (also producing ammonia) or, following uptake by nucleoside transporters, via adenosine deaminase or adenosine kinase (requiring ATP as co-substrate). Intracellular adenosine may be produced by cytosolic 5'-nucleotidases or through Sadenosylhomocysteine hydrolase (also producing L-homocysteine).
\end{abstract}

\section{Contents}

This is a citation summary for Adenosine turnover in the Guide to Pharmacology database (GtoPdb). It exists purely as an adjunct to the database to facilitate the recognition of citations to and from the database by citation analyzers. Readers will almost certainly want to visit the relevant sections of the database which are given here under database links.

GtoPdb is an expert-driven guide to pharmacological targets and the substances that act on them. GtoPdb is a reference work which is most usefully represented as an on-line database. As in any publication this work should be appropriately cited, and the papers it cites should also be recognized. This document provides a citation for the relevant parts of the database, and also provides a reference list for the research cited by those parts. For further details see [12].

Please note that the database version for the citations given in GtoPdb are to the most recent preceding version in which the family or its subfamilies and targets were substantially changed. The links below are to the current version. If you need to consult the cited version, rather than the most recent version, please contact the GtoPdb curators.

\section{Database links}

Adenosine turnover

https://www.guidetopharmacology.org/GRAC/FamilyDisplayForward?familyId=248

Introduction to Adenosine turnover

https://www.guidetopharmacology.org/GRAC/FamilyIntroductionForward?familyId=248

Enzymes

ADA(Adenosine deaminase)

https://www.guidetopharmacology.org/GRAC/ObjectDisplayForward?objectId=1230

ADK(Adenosine kinase)

https://www.guidetopharmacology.org/GRAC/ObjectDisplayForward?objectId=1231

NT5E(Ecto-5'-Nucleotidase)

https://www.guidetopharmacology.org/GRAC/ObjectDisplayForward?objectId=1232 SAHH(S-Adenosylhomocysteine hydrolase)

https://www.guidetopharmacology.org/GRAC/ObjectDisplayForward?objectId=1233

5'-nucleotidase IA

https://www.guidetopharmacology.org/GRAC/ObjectDisplayForward?objectId=1234

5'-nucleotidase IB

https://www.guidetopharmacology.org/GRAC/ObjectDisplayForward?objectId=1235

5'-nucleotidase II

https://www.guidetopharmacology.org/GRAC/ObjectDisplayForward?objectId=1236 
5'-nucleotidase III

https://www.guidetopharmacology.org/GRAC/ObjectDisplayForward?objectId=1237

5'(3')-nucleotidase

https://www.guidetopharmacology.org/GRAC/ObjectDisplayForward?objectId=1238

Mitochondrial 5'-nucleotidase

https://www.guidetopharmacology.org/GRAC/ObjectDisplayForward?objectId=1239

\section{References}

1. Agarwal RP, Spector T and Parks Jr RE. (1977) Tight-binding inhibitors--IV. Inhibition of adenosine deaminases by various inhibitors. Biochem Pharmacol 26: 359-67 [PMID:849330]

2. Antonioli L, Blandizzi C, Pacher P and Haskó G. (2013) Immunity, inflammation and cancer: a leading role for adenosine. Nat Rev Cancer 13: 842-57 [PMID:24226193]

3. Antonioli L, Pacher P, Vizi ES and Haskó G. (2013) CD39 and CD73 in immunity and inflammation. Trends Mol Med 19: 355-67 [PMID:23601906]

4. Baqi Y, Lee SY, Iqbal J, Ripphausen P, Lehr A, Scheiff AB, Zimmermann H, Bajorath J and Müller CE. (2010) Development of potent and selective inhibitors of ecto-5'-nucleotidase based on an anthraquinone scaffold. J Med Chem 53: 2076-86 [PMID:20146483]

5. Bastid J, Cottalorda-Regairaz A, Alberici G, Bonnefoy N, Eliaou JF and Bensussan A. (2013) ENTPD1/CD39 is a promising therapeutic target in oncology. Oncogene 32: 1743-51 [PMID:22751118]

6. Beamer E, Gölöncsér F, Horváth G, Bekő K, Otrokocsi L, Koványi B and Sperlágh B. (2016) Purinergic mechanisms in neuroinflammation: An update from molecules to behavior. Neuropharmacology 104: 94-104 [PMID:26384652]

7. Bhattarai S, Pippel J, Scaletti E, Idris R, Freundlieb M, Rolshoven G, Renn C, Lee SY, Abdelrahman A and Zimmermann $\mathrm{H}$ et al.. (2020) 2-Substituted $\alpha, \beta$-Methylene-ADP Derivatives: Potent Competitive Ecto-5'-nucleotidase (CD73) Inhibitors with Variable Binding Modes. J Med Chem 63: 2941-2957 [PMID:32045236]

8. Boison D. (2013) Adenosine kinase: exploitation for therapeutic gain. Pharmacol Rev 65: 906-43 [PMID:23592612]

9. Borea PA, Gessi S, Merighi S and Varani K. (2016) Adenosine as a Multi-Signalling Guardian Angel in Human Diseases: When, Where and How Does it Exert its Protective Effects? Trends Pharmacol Sci 37: 419-34 [PMID:26944097]

10. Borea PA, Gessi S, Merighi S, Vincenzi F and Varani K. (2017) Pathological overproduction: the bad side of adenosine. Br J Pharmacol 174: 1945-1960 [PMID:28252203]

11. Bowman CE, da Silva RG, Pham A and Young SW. (2019) An Exceptionally Potent Inhibitor of Human CD73. Biochemistry 58: 3331-3334 [PMID:31334635]

12. Buneman P, Christie G, Davies JA, Dimitrellou R, Harding SD, Pawson AJ, Sharman JL and Wu Y. (2020) Why data citation isn't working, and what to do about it Database 2020 [PMID:32367113]

13. Burger RM and Lowenstein JM. (1975) 5'-Nucleotidase from smooth muscle of small intestine and from brain. Inhibition of nucleotides. Biochemistry 14: 2362-6 [PMID:1169962]

14. Cortés A, Gracia E, Moreno E, Mallol J, Lluís C, Canela EI and Casadó V. (2015) Moonlighting adenosine deaminase: a target protein for drug development. Med Res Rev 35: 85-125 [PMID:24933472]

15. Geoghegan JC, Diedrich G, Lu X, Rosenthal K, Sachsenmeier KF, Wu H, Dall'Acqua WF and Damschroder MM. (2016) Inhibition of CD73 AMP hydrolysis by a therapeutic antibody with a dual, non-competitive mechanism of action. MAbs 8: 454-67 [PMID:26854859]

16. Glazer RI, Hartman KD, Knode MC, Richard MM, Chiang PK, Tseng CK and Marquez VE. (1986) 3-Deazaneplanocin: a new and potent inhibitor of S-adenosylhomocysteine hydrolase and its effects on human promyelocytic leukemia cell line HL-60. Biochem Biophys Res Commun 135: 688-94 [PMID:3457563]

17. Guranowski A, Montgomery JA, Cantoni GL and Chiang PK. (1981) Adenosine analogues as substrates and inhibitors of S-adenosylhomocysteine hydrolase. Biochemistry 20: 110-5 [PMID:7470463]

18. Haskó G, Linden J, Cronstein B and Pacher P. (2008) Adenosine receptors: therapeutic aspects for inflammatory and immune diseases. Nat Rev Drug Discov 7: 759-70 [PMID:18758473]

19. Häusler SF, Del Barrio IM, Diessner J, Stein RG, Strohschein J, Hönig A, Dietl J and Wischhusen J. (2014) Anti-CD39 and anti-CD73 antibodies A1 and 7G2 improve targeted therapy in ovarian cancer by blocking adenosine-dependent immune evasion. Am J Transl Res 6: 129-39 [PMID:24489992]

20. Jarvis MF, Yu H, Kohlhaas $\mathrm{K}$, Alexander $\mathrm{K}$, Lee $\mathrm{CH}$, Jiang M, Bhagwat SS, Williams $\mathrm{M}$ and Kowaluk EA. (2000) ABT-702 (4-amino-5-(3-bromophenyl)-7-(6-morpholinopyridin-3-yl)pyrido[2, 3-d]pyrimidine), a novel orally effective adenosine kinase inhibitor with analgesic and antiinflammatory properties: I. In vitro characterization and acute antinociceptive effects in the 
mouse. J Pharmacol Exp Ther 295: 1156-64 [PMID:11082453]

21. Kameoka J, Tanaka T, Nojima Y, Schlossman SF and Morimoto C. (1993) Direct association of adenosine deaminase with a T cell activation antigen, CD26. Science 261: 466-9 [PMID:8101391]

22. Leclerc BG, Charlebois R, Chouinard G, Allard B, Pommey S, Saad F and Stagg J. (2016) CD73 Expression Is an Independent Prognostic Factor in Prostate Cancer. Clin Cancer Res 22: 158-66 [PMID:26253870]

23. Loi S, Pommey S, Haibe-Kains B, Beavis PA, Darcy PK, Smyth MJ and Stagg J. (2013) CD73 promotes anthracycline resistance and poor prognosis in triple negative breast cancer. Proc Natl Acad Sci USA 110: 11091-6 [PMID:23776241]

24. Lu XX, Chen YT, Feng B, Mao XB, Yu B and Chu XY. (2013) Expression and clinical significance of CD73 and hypoxia-inducible factor- $1 \alpha$ in gastric carcinoma. World J Gastroenterol 19: 1912-8 [PMID:23569336]

25. Maier SA, Galellis JR and McDermid HE. (2005) Phylogenetic analysis reveals a novel protein family closely related to adenosine deaminase. J Mol Evol 61: 776-94 [PMID:16245011]

26. McGaraughty S, Chu KL, Wismer CT, Mikusa J, Zhu CZ, Cowart M, Kowaluk EA and Jarvis MF. (2001) Effects of A-134974, a novel adenosine kinase inhibitor, on carrageenan-induced inflammatory hyperalgesia and locomotor activity in rats: evaluation of the sites of action. $J$ Pharmacol Exp Ther 296: 501-9 [PMID:11160637]

27. Ren ZH, Lin CZ, Cao W, Yang R, Lu W, Liu ZQ, Chen YM, Yang X, Tian Z and Wang LZ et al.. (2016) CD73 is associated with poor prognosis in HNSCC. Oncotarget 7: 61690-61702 [PMID:27557512]

28. Roifman CM, Zhang J, Atkinson A, Grunebaum E and Mandel K. (2008) Adenosine deaminase deficiency can present with features of Omenn syndrome. J Allergy Clin Immunol 121: 1056-8 [PMID:18243287]

29. Stagg J. (2012) The double-edge sword effect of anti-CD73 cancer therapy. Oncoimmunology 1: 217-218 [PMID:22720247]

30. Villa A, Notarangelo LD and Roifman CM. (2008) Omenn syndrome: inflammation in leaky severe combined immunodeficiency. J Allergy Clin Immunol 122: 1082-6 [PMID:18992930]

31. Wang H, Lee S, Nigro CL, Lattanzio L, Merlano M, Monteverde M, Matin R, Purdie K, Mladkova $\mathrm{N}$ and Bergamaschi D et al.. (2012) NT5E (CD73) is epigenetically regulated in malignant melanoma and associated with metastatic site specificity. Br J Cancer 106: 1446-52 [PMID:22454080]

32. Wang L, Fan J, Thompson LF, Zhang Y, Shin T, Curiel TJ and Zhang B. (2011) CD73 has distinct roles in nonhematopoietic and hematopoietic cells to promote tumor growth in mice. J Clin Invest 121: 2371-82 [PMID:21537079]

33. Williams-Karnesky RL, Sandau US, Lusardi TA, Lytle NK, Farrell JM, Pritchard EM, Kaplan DL and Boison D. (2013) Epigenetic changes induced by adenosine augmentation therapy prevent epileptogenesis. J Clin Invest 123: 3552-63 [PMID:23863710]

34. Wu XR, He XS, Chen YF, Yuan RX, Zeng Y, Lian L, Zou YF, Lan N, Wu XJ and Lan P. (2012) High expression of CD73 as a poor prognostic biomarker in human colorectal cancer. J Surg Oncol 106: 130-7 [PMID:22287455]

35. Zavialov AV, Yu X, Spillmann D, Lauvau G and Zavialov AV. (2010) Structural basis for the growth factor activity of human adenosine deaminase ADA2.J Biol Chem 285: 12367-77 [PMID:20147294] 